\title{
Influence of the glutathione s-transferase gene polymorphisms on the susceptibility to basal cell skin carcinoma
}

\author{
Janaína L Leite, Elaine C Morari, Fabiana Granja, Gabriela \\ M Campos, Ana CT G uilhen, Laura S. W ard.
}

Background: The identification of groups at high risk is fundamental to determine preventive strategies for skin cancer. Destructive reactive oxygen species produced by UVA or chemical carcinogens are metabolized by a series of enzymes. Polymorphisms of genes encoding for these enzymes may produce defective proteins with a diminished ability to detoxify a wide range of carcinogens. Aims: To ascertain the influence and potential interactions of several polymorphisms of genes encoding four important antioxidant GST enzymes in the susceptibility to cancer among Brazilians. Material and methods: We compared the genotypes of Glutathione S-Transferase mu, theta, pi and omega (GSTM1, GSTT1, GSTP1 and GSTO2) in a group of 102 patients with skin lesions and 124 controls. Results: Patients with Basal Cell Skin Carcinoma (BCC) presented the combined GSTM1-GSTT1+ genotype more frequently $(49.1 \%)$ than controls (29.8\%) (Fisher test; $\mathrm{p}=0.04$ ), conferring a 2.273 (Odds Ratio; 95\% CI $=1.199-4.308$ ) higher risk for BCC. We were not able to find any other association between genotypes or between any genotype and the patients' clinical features. Conclusions: The GST profile may help identify Brazilian individuals at higher risk for BCC (Rev Méd Chile 2007; 135: 301-6).

(Key words: Carcinoma, basal cell; Glutathione Stransferase; Polymorphism, genetic)

Recibido el 8 de junio, 2006. Aceptado el 29 de agosto, 2006.

Financial support: This work was supported by grants from FAPESP 03/02309-7 and 03/ 07881-0 and from CNPQ 305775/2004-9.

Laboratory of Cancer Molecular Genetics, Department of Medicine, School of Medicine, State University of Campinas (UNICAMP), Campinas, São Paulo, Brazil

\section{Influencia de polimorfismos de genes de glutation s-transferasa en la susceptibilidad a carcinoma cutáneo de células basales}

Antecedentes: La identificación de grupos en riesgo elevado es fundamental en la determinación de las estrategias preventivas para el cáncer de la piel, el maligno humano más común. Las especies reactivas destructivas del oxígeno producidas por UVA o los agentes carcinógenos químicos son metabolizadas por una serie de enzimas. Los polimorfismos de los genes que codifican para estas enzimas pueden producir las enzimas defectuosas con una

Corresponding Author: Laura S. Ward, MD, PhD. Laboratory of Cancer Molecular Genetics FCM - UNICAMP. Tessalia Vieira de Camargo 126 13081-970, Campinas, São Paulo, Brazil. Phone/Fax: 55193289 4107. E mail: ward@unicamp.br 
capacidad disminuida de desintoxicar una amplia gama de agentes carcinógenos. Objetivo: Este estudio fue diseñado para comprobar las interacciones de la influencia y del potencial de varios polimorfismos de los genes que codificaban 4 enzimas importantes del antioxidante GST en la susceptibilidad al cáncer entre brasileños. Métodos: Comparamos los genotipos del mu del S Transferase del Glutathione, de la theta, de pi y de Omega (GSTM1, GSTT1, GSTP1 y GSTO2) en un grupo de 102 lesiones de piel y de 124 controles. Resultados: Los pacientes con el carcinoma basocelular (BCC) presentaron el genotipo combinado de GSTM1-GSTT1+ más frecuente $(49,1 \%)$ que los controles $(29,8 \%$ ) (Fisher test; $\mathrm{p}=0,04$ ), confiriendo 2.273 (Odds Ratio 95\% CI $=1.199$ 4.308) un riesgo más alto para BCC. No encontramos ninguna otra asociación entre los genotipos 0 entre ningún genotipo y características clínicas de los pacientes. Conclusiones: Sugerimos que el perfil de GST pueda ayudar a identificar a individuos brasileños en un riesgo más alto para BCC.

$\mathrm{C}$ ancer of the skin is the most common malignancy in human beings. More than one million cases occur every year and the worldwide raise in this incidence to near epidemic proportions has led to increased morbidity and appreciating costs in many countries ${ }^{1}$. Variations of skin cancer incidence in different geographic and ethnic groups suggest that environmental factors have a strong influence in the skin tumorigenic process. In fact, there are compelling clinical, epidemiological and experimental evidences of environmental risk factors including ultraviolet (UVR) and ionizing radiations, cell-transforming viruses, immunosuppression and an increasing list of chemical carcinogens ${ }^{1}$. However, humans vary greatly in their likelihood of developing cancer in response to the natural hazards that they are constantly exposed to. Individual differences in susceptibility to carcinogens play an essential role in the development of sporadic tumors. The biochemical basis for this susceptibility is related to genetic polymorphisms that normally occur in the general population regarding genes involved in predisposition to a specific cancer, in the metabolic activation or detoxification of environmental genotoxins, and in controlling DNA repair or cellular damage ${ }^{2-4}$. Among the several polymorphic genes encoding for enzymes involved in free radical metabolism and biotransformation of carcinogens that have been investigated as possible cancer risk modifiers, the glutathione $\mathrm{S}$ transferase gene system (GST) is one of the most well-known ${ }^{4,5}$. It consists of a large multigenic group of detoxifying enzymes whose activity, catalyzing the conjugation of toxic and mutagenic compounds with glutathione, is essential for cell protection $^{5,6}$. Four classes of isoenzymes have been related to human malignancy: mu (GSTM), pi (GSTP), omega (GSTO) and theta (GSTT). Several studies, including our own, have shown that individuals who are deletion homozygote for GSTM1 or GSTT1, as well as individuals that present GSTP1 variants (GSTv) resulting from an aminoacid substitution (1105Valine) at exon 5 of GSTP1, are at increased risk for a series of tumors ${ }^{2-}$ $4,7,8$. GST enzymes are implicated in the detoxification of lipid and DNA products of UVR-derived oxidative stress and allelic variants at GSTs are associated with outcome of various oxidative-stress related diseases, including skin cancer ${ }^{9-13}$.

More recently, genetic polymorphisms of GSTO gene were described including GSTO2 N142D, a variant at base $424^{14}$. These polymorphisms have been related to a lower capacity of the corresponding enzymes to metabolize arsenic, a well-known skin carcinogenic chemical ${ }^{14,15}$.

The genetic profiles of each population, its occupational pattern, alimentary and social characteristics are fundamental in determining the susceptibility to some tumors. In addition, a balance between several antioxidant enzymes may be more important than the activity of a single enzyme alone for the overall protective capacity against free radical-mediated damage, and deficiencies of one gene may be partially compensated for by other related genes, stressing the importance of determining the genetic profile of specific populations. Brazilian population is particularly interesting due to its highly heterogeneous background and racial admixture, and data on the influence of its genetics on skin cancer susceptibility are still scarce.

Hence, the present case-control prospective study was designed to ascertain the influence and potential interactions of genes encoding 4 important antioxidant GST enzymes in the susceptibility to cancer among Brazilians. 


\section{Patients AND Methods}

The study was approved by the Ethics Committees of the University Hospital-School of Medicine of the State University of Campinas (HC-FCM/UNICAMP), and informed written consent was obtained from all individuals.

One hundred and two unrelated adult patients consecutively referred for skin lesion evaluation, that agreed to participate, were enrolled in the study. The study population was composed of 29 squamous cell carcinomas (SCC), 59 basal cell carcinoma (BCC), 5 malignant melanomas (MM) and 9 non-malignant lesions (benign). All patients were carefully examined and previous medical conditions were particularly considered, especially organ transplantation, immunosuppressive therapy, other malignancies and HIV infection.

A control group of 124 healthy blood donors individuals (61 males and 63 females, 36 to 96 years old, $64.12 \pm 19.34$ years old) was selected from the general population of our region through HC/FCM/ UNICAMP. Because of the high ethnic mixture and heterogeneity of the Brazilian population, all individuals were classified into whites (or Euro-Brazilians) and non-whites in accordance with the Brazilian Institute of Geography and Statistics (IBGE, 2003). Data on UV and possible chemicals exposure, ethnic background as well as age and sex were considered in order to obtain a control group similar to the patients group. All individuals lived in urban areas. Individuals suspected of any immunosuppressive condition or to have been recurrently exposed to any chemicals were excluded.

Blood specimens were obtained from all patients and control individuals simultaneously with tissues samples from patients with lesions. Genomic DNA was extracted from frozen specimens and leukocytes separated from whole blood using a standard proteinase-K-phenol-chloroform protocol. A multiplex-Polimerase Chain Reaction (PCR) assay was used to simultaneously amplify the GSTT1 and GSTM1 genes as previously described $^{8}$. GSTP1 and GSTO2 variants were studied using PCR-RFLP (restriction fragment length polymorphism) assays. For GSTP1, the PCR was performed in $25 \mu \mathrm{l}$ volumes of a mixture containing $100 \mathrm{ng}$ DNA, $10 \mu \mathrm{M}$ of each primer, $10 \mathrm{mM}$ Tris- $\mathrm{HCl}(\mathrm{pH} 8.0), 0.1 \mathrm{mM}$ of each dinucleotide triphosphate, $2.0 \mathrm{mM} \mathrm{MgCl} 2$ and $0.5 \mathrm{U}$ Taq DNA polymerase. Amplifications were carried out for 35 cycles of $94^{\circ} \mathrm{C}$ for 45 seconds, annealing temperatures $62.4^{\circ} \mathrm{C}$ for 45 seconds and $72^{\circ} \mathrm{C}$ for $1 \mathrm{~min}$, with an initial denaturation step of $94^{\circ} \mathrm{C}$ for $5 \mathrm{~min}$ and a final extension step of $72^{\circ} \mathrm{C}$ for $7 \mathrm{~min}$ using a Termocycler MJPTC-200 PCR System. The pair of primers for GSTP1 (5' CCAGGCTGGGGCTCACAGACAGC3'/5'GGTCAGCCCAAGCCACCTGAGG3') amplified a fragment of 306bp. For GSTO2, we used the same conditions as above with annealing temperature of $62^{\circ} \mathrm{C}$. The pair of primers for GSTO2 (5'ACTGAGAACCGGAACCACAG3'/5'GTACCTCTTCCAGGTTG3') amplified a fragment of 280bp. RFLP was carried out using Alw26I (BsmAI) and MboI enzymes for GSTP1 and GSTO2 assays respectively, according to the manufacturer's protocol (Fermentas Life Sciences). The fragments were analyzed after electrophoresis on a $3.0 \%$ agarose gel. Six samples from each assay were directly sequenced and confirmed to be the PCR predicted variants. Positive and negative control samples were included in all PCR and RFLP runs to detect possible contamination problems, gel loading and typing inconsistencies.

Statistical analysis was conducted using SAS (Statistical Analysis System, version 8.1, SAS Institute Inc, Cary, NC, USA, 1999-2000). Associations were assessed using $2 \mathrm{X} 2$ or $2 \mathrm{Xn}$ contingency table analysis and Chi-square $\left(\chi^{2}\right)$ or Fisher's $(F)$ exact tests were used where appropriate. Kruskal-Wallis (KW) test was used to compare age among groups. MannWhitney or Wilcoxon tests were used to compare age among different genotype groups. Odds ratio (OR) and 95\% confidence interval (CI) were used to analyze the frequency of phenotypes since they provide a measure of the strength of association, compared to the control population. All tests were conducted at the $\mathrm{p}=0.05$ level of significance.

\section{RESULTS}

The clinical features of the control individuals and the skin lesion patients are summarized in Table 1 where we also present the overall genotyping profile of the studied groups. There were no differences between the control and the skin disease patients regarding gender (61 males and 63 females versus 53 males and 49 females), age $(64.12 \pm 19.34$ years versus $64.11 \pm 15.64)$ and eth- 
Table 1. D istribution of the control individuals and patients. This distribution is according to their skin lesions histology, clinical features including age (X+SD in years), gender (F: female; $M$ : male), ethnicity (W: white, NW: non-white), and the corresponding genotype for GST M 1, GST T 1, GST P1 and GST 0 2. G enotypes are represented as + (present) or - (absent) according to the presence of the allele or WT, H ET and H 0 according to the presence of a wild type, a heterozygous or a homozygous variant form of the gene, respectively

\begin{tabular}{|c|c|c|c|c|c|c|c|c|c|c|c|c|c|c|c|}
\hline \multirow[t]{3}{*}{ Histology } & \multicolumn{5}{|c|}{ Clinical characteristics } & \multicolumn{10}{|c|}{ Genotype } \\
\hline & \multirow{2}{*}{$\begin{array}{c}\text { Age } \\
(\overline{\mathrm{x}} \pm \mathrm{SD})\end{array}$} & \multicolumn{2}{|c|}{ Sex } & \multicolumn{2}{|c|}{ Ethnicity } & \multicolumn{2}{|c|}{ GSTM1 } & \multicolumn{2}{|c|}{ GSTT1 } & \multicolumn{3}{|c|}{ GSTP1 } & \multicolumn{3}{|c|}{ GSTO2 } \\
\hline & & $\mathrm{M}$ & $\mathrm{F}$ & W & NW & + & - & + & - & WT & HET & $\mathrm{HO}$ & WT & HET & HO \\
\hline $\begin{array}{l}\text { Controls } \\
(\mathrm{N}=124)\end{array}$ & $64.12 \pm 19.34$ & 61 & 63 & 98 & 26 & 72 & 52 & 96 & 28 & 60 & 46 & 18 & 40 & 62 & 22 \\
\hline$(\mathrm{N}=9)$ & $61.66 \pm 20.44$ & 3 & 6 & 9 & 0 & 5 & 4 & 7 & 2 & 7 & 1 & 1 & 3 & 5 & 1 \\
\hline $\begin{array}{l}\text { BCC } \\
(\mathrm{N}=59)\end{array}$ & $67.42 \pm 11.18$ & 33 & 26 & 58 & 1 & 25 & 34 & 49 & 10 & 35 & 20 & 4 & 25 & 26 & 8 \\
\hline $\begin{array}{l}\text { SCC } \\
(\mathrm{N}=29)\end{array}$ & $56.16 \pm 19.23$ & 16 & 13 & 29 & 0 & 28 & 13 & 22 & 7 & 14 & 13 & 2 & 12 & 12 & 5 \\
\hline $\begin{array}{l}\mathrm{MM} \\
(\mathrm{N}=5)\end{array}$ & $75.8 \pm 6.94$ & 1 & 4 & 4 & 1 & 4 & 1 & 2 & 3 & 1 & 1 & 3 & 2 & 2 & 1 \\
\hline
\end{tabular}

Table 2. Comparison among the distribution of the different combinations of GST T 1 and G ST M 1 genotypes in the control population and the skin benign and malignant cases, including basal cell carcinoma (BCC), squamous cell carcinomas (SCC) and malignant melanomas (M M )

\begin{tabular}{|c|c|c|c|c|c|c|c|c|}
\hline \multirow[t]{2}{*}{ Genotype } & Population & Benign & \multicolumn{2}{|c|}{ BCC } & \multicolumn{2}{|r|}{ SCC } & \multicolumn{2}{|r|}{ MM } \\
\hline & $(\%)$ & $\mathrm{N}$ & $\mathrm{N}$ & $\%$ & $\mathrm{~N}$ & $\%$ & $\mathrm{~N}$ & $\%$ \\
\hline GSTT1-GSTM1- & 15 (12.09) & 1 (11.11) & & $(8.47)$ & & (6.89) & 1 & (20.00) \\
\hline GSTT1-GSTM1+ & $13(10.48)$ & $1(11.11)$ & & $(8.47)$ & 5 & (17.24) & 2 & $(40.00)$ \\
\hline GSTT1+GSTM- & 37 (29.83) & $3(33.33)$ & & (49.15) & 11 & (37.93) & 0 & \\
\hline GSTT1+GSTM1+ & 59 (47.58) & $4(44.44)$ & & (33.89) & 11 & (37.93) & 2 & $(40.00)$ \\
\hline Total & 124 & 9 & & 59 & & 29 & & 5 \\
\hline
\end{tabular}

nicity (118 white and 6 non-white versus 100 white and 2 non-white individuals) (F: $\mathrm{p}<0.0001$ ).

Genotyping of the different types of cancer is presented in Tables 1 and 2. The combined GSTT1+GSTM1- genotype was more frequent among BCC patients (49.1\%) than in the control group (29.8\%) ( $\mathrm{F}: \mathrm{p}=0.04)$. Hence, this genotype conferred a 2.273 (OR: 95\% CI =1.199-4.308) higher risk for BCC compared to other GSTM1 and GSTT1 combinations of genotypes. GSTP1 did not differ in control and skin benign lesions' patients or nonmelanoma cancers. However, 3 out of the $5 \mathrm{MM}$ patients presented a homozygous GSTP1 variant, in contrast to the low prevalence of this variant in the control population (14.5\%) (F: $p=0.0303)$. The presence of a homozygotic variant of GSTP1 gene conferred an 8.8 times higher susceptibility to $\mathrm{MM}$ (OR =8.883; 95\% CI =1.378-56.636).

We were not able to find any significant difference in the rate of any other GST normal or variant alleles in the different types of malignant tumors. There was no association between any other genotypes or between any genotype and the patients' clinical features.

\section{DisCUSSION}

Cancer of the skin is one of the most powerful examples of how human tumors are a result of the interaction between environmental factors and 
personal genetic susceptibility. The most common factor involved in the pathogenesis of non-melanoma skin cancers is the exposure to UVR. However, exposure to large amounts of arsenic, industrial tar, coal, paraffin, certain types of oil, and other chemicals may increase the risk to nonmelanoma skin tumors too ${ }^{1}$. One of the mechanisms by which UV light mediates its carcinogenic effect is by stimulating the production of reactive oxygen species, which trigger both DNA damage and abnormal cytoplasmic signal transduction ${ }^{16}$.

Glutathione S-transferases are an important group of antioxidant enzymes that may have evolved to protect cells against reactive oxygen metabolites. The present study demonstrates that the combined GSTT1+GSTM1- genotype predisposes to the development of BCC. Also, the presence of a GSTP1 variant in homozygosis increased the risk for $\mathrm{MM}$, although the small number of cases examined prevents any further conclusion. On the other hand, the present genotyping profile of skin lesions' patients and controls resulted similar to the genetic profile described earlier by our own group and also to other reports on different types of tumors in Brazil 7,8,17-20.

The precise mechanism of action of GST enzymes is as yet largely unknown but it is accepted that they act via modification of DNA and lipid damage to key tumor suppressor genes or by protection against relevant carcinogens ${ }^{4,5,16,21}$. GSTM1 null genotype has been associated to non-melanoma carcinoma risk, especially in males with multiple BCC and immunosuppressed patients $9,10,12$. In addition, in patients with systemic lupus erithematosus, GSTM1 null was associated with increased production of anti-Ro antibodies, a phenotype associated with marked photosensitivity ${ }^{22}$. Our data suggest a protective effect of the GSTT1 null genotype when combined to GSTM1 null genotype. Other studies have suggested that some detoxifying enzymes may exert a protective effect on some types of tumors, depending on the source of exposure ${ }^{23}$. For instance, in vitro studies, mostly conducted on metabolites of butadiene, confirm a protective

\section{REFERENCES}

1. Aimahroos M, Kurban AK. Ultraviolet carcinogenesis in nonmelanoma skin cancer. Part I: incidence rates action of GSTT1 23 . Indeed, some epoxides are scavenged in-vitro systems by GSTT1 and are less dangerous for GSTT1 positive subjects ${ }^{23}$.

There are evidences for a role of GSTP1 in the pathogenesis of skin malignancies. GSTP1 is a major antioxidant in both the epidermis and the dermis, and is overexpressed in a variety of preneoplastic and neoplastic tissues ${ }^{24}$. However, our data do not support an important role of GSTP1 in non-melanoma skin cancer and the small number of MM we studied prevents any conclusion regarding this type of tumor.

We included GSTO2 polymorphism in this study because of GSTO variants lower capacity to biotransform inorganic arsenic ${ }^{14,15}$. Arsenic is a notorious environmental skin carcinogen and contamination of drinking water with inorganic arsenic is a worldwide health problem ${ }^{24}$. A recent expression pattern analysis revealed that GSTO2 was ubiquitously expressed at a low level in all tissues and suggested that it may play an important role in cellular signaling ${ }^{25}$. However, our data do not indicate an important role of GSTO2 in skin cancer carcinogenesis.

It is important to note that the influence of any single genetic polymorphism may have a small contribution on the susceptibility to cutaneous malignancy that is influenced by a multitude of genes that may either protect against or increase the susceptibility to an increasing list of chemical, physical and biological carcinogens. Also, the different GST enzymes have specific endogenous and environmental substrates, a fact that helps explain the difference rate for many cancers described in different populations.

In conclusion, we observed an association between GSTM1 and GSTT1 genotype and the risk for BCC. Although the risk presented by this association had a relatively small OR, it may help to understand the basis of genetic and environmental factors known to predispose to skin cancer, and, therefore, sort out individuals that deserve a special medical attention. Further studies including a larger number of patients are necessary to clarify the role of these genotypes in skin cancer susceptibility and their interaction with genotoxic or cytotoxic agents.

in relation to geographic locations and in migrant populations. Skinmed 2004; 3: 29-36.

2. CLAPPER ML Genetic polymorphism and cancer risk. Curr Oncol Rep 2000; 2: 251-6. 
3. LChtenstein P, Holm NV, Verkasalo PK, Inadou A, KapRIO J, KoSKEnvUO M ET AL. Environmental and heritable factors in the causation of cancer-analyses of cohorts of twins from Sweden, Denmark, and Finland. NEngl J Med 2000; 343: 78-85.

4. VINEIS P. Cancer as an evolutionary process at the cell level: an epidemiological perspective. Carcinogenesis 2003; 24: 1-6.

5. MANNERVIK B. The isozymes of glutathione Stransferase. Adv Enzymol 1985; 57: 357-417.

6. KNUDSEN LE, LOFT SH, AutruP H. Risk assessment: the importance of genetic polymorphisms in man. Mutat Res 2001; 482: 83-8.

7. Granja F, Morari J, Morari E, Correa L, Assumpção L, WARD L GST profiling may be useful in the screening for thyroid nodule malignancy. Cancer Letters 2004; 209: 129-37.

8. Morari EC, Leite JLP, Granja F, Assumpção LVM, Ward LS. The null genotype of glutathione s-transferase M1 and T1 locus increases the risk for thyroid cancer. Cancer Epidemiol Bio \& Prev 2002; 11: 1485-8.

9. Cariess MA, Lfa RA, Curran JE, Appieyard B, Gaffney $P$, GREEN A, GRIFFTHS LR. The GSTM1 null genotype confers an increased risk for solar keratosis development in an Australian Caucasian population. J Invest Dermatol 2002; 119: 1373-8.

10. Fryer AA, Ramsay HM, Lovatt TJ, Jones PW, Hawiey CM, NICOL DL ET AL. Polymorphisms in glutathione $S$ transferases and non-melanoma skin cancer risk in Australian renal transplant recipients. Carcinogenesis 2005; 26: 185-91.

11. Kanetsky PA, Holmes R, Waiker A, Najarian D, Swoyer J, GUERRY D ET AL. Interaction of glutathione Stransferase M1 and T1 genotypes and malignant melanoma. Cancer Epidemiol Biomarkers Prev 2001; 10: 509-13.

12. Kerb R, Brockmoler J, Schiagenhaufer R, Sprenger $R$, Roots I, BRINKMANN U. Influence of GSTT1 and GSTM1 genotypes on sunbum sensitivity. Am J Pharmacogenomics 2002; 2: 147-54.

13. Lfar JT, Smith AG, Strange RC, Fryer AA. Detoxifying enzyme genotypes and susceptibility to cutaneous malignancy. Br J Dermatol 2000; 142: 8-15.

14. Whitbread AK, TetLow N, Eyre HJ, Sutherdand GR, BOARD PG. Characterization of the human omega class glutathione transferase genes and associated polymorphisms. Pharmacogenetics 2003; 13: 131-44.

15. Tanaka-Kagana T, Jinno H, Hasegana T, Makino Y, Seko Y, НANIOKA N ET AL. Functional charactenzation of two variant human GSTO1-1s (Ala140Asp and Thr217Asn). Biochem Biophys Res Commun 2003; 301: 516-20.
16. TyreIL RM. UV activation of mammalian stress proteins. EXS 1996; 77: 255-71.

17. Gattás GJF, Kato M, Soares-Vielra Ja, Siraque MS, KoHIER P, Gomes L ET AL. Ethnicity and glutathione Stransferase (GSTM1/GSTT1) polymorphisms in a Brazilian population. Braz J Med Biol Res 2004; 37: 451-8.

18. Granja F, Morari EC, Assumpção LVM, Ward LS. GSTO polymorphism analyses in thyroid nodules suggest that GSTO1 variants do not influence the risk for malignancy. Eur J Cancer Prev 2005; 14: 277-80.

19. Nascimento H, Coy CS, Teori MT, Boin IF, Goes JR, Costa FF ET AL Possible influence of glutathione S transferase GSTT1 null genotype on age of onset of sporadic colorectal adenocarcinoma. Dis Colon Rectum 2003; 46: 510-5.

20. Rossini A, Rapozo DC, Amorim LM, Macedo JM, Medina R, Neto JF et al. Frequencies of GSTM1, GSTT1, and GSTP1 polymorphisms in a Brazilian population. Genet Mol Res 2002; 1: 233-40.

21. Ketterer B, Taylor J, Meyer D. Some functions of glutathione transferases, in: K. Tew, B. Mannervik, T.J. Mantle, C.B. Pickett and J.D. Hayes, eds. In Structure and Function of Glutathione Transferases CRC Press: Boca Raton, FL 1993; 15-27.

22. Heagerty A, Smith A, English J, Lfar J, Perkins W, BowERS B ET AL. Susceptibility to multiple cutaneous basal cell carcinomas: significant interactions between glutathione Stransferase GSTM1 genotypes, skin type and male gender. Br J Cancer 1996; 73: 44-8.

23. Ower W, Davies E, Snowden N, Audersea J, Fryer A, JONES P ET AL. Association of homozygosity for glutathione-S-transferase GSTM1 null alleles with the Ro + La- autoantibody profile in patients with systemic lupus erythematosus. Arthritis Rheum 1996; 39: 1763-4.

24. LANDI S. Mammalian class theta GST and differential susceptibility to carcinogens: a review. Mutat Res 2000; 463: 247-83.

25. Rossman TG, Uddin AN, Burns FJ. Evidence that arsenite acts as a cocarcinogen in skin cancer. Toxicol Appl Pharmacol 2004; 1macol 2004; 198: 394-404.

\section{Aknowledgments}

We are grateful to Dr. Hamilton Ometto Stolf, dermatologist from UNESP-Botucatu-SP, and Dr Aparecida M. Moraes-UNICAMP-Campinas-SP for kindly providing the samples used in this study. 